\title{
The protective role of myeloid-derived suppressor cells in concanavalin A-induced hepatic injury
}

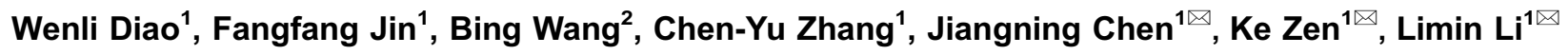 \\ 1 Jiangsu Engineering Research Center for MicroRNA Biology and Biotechnology, State Key Laboratory of Pharmaceutical \\ Biotechnology, School of Life Sciences, Nanjing University, Nanjing 210093, China \\ 2 People's Liberation Army 404 Hospital, Weihai 264200, China \\ $\triangle$ Correspondence: jnchen@nju.edu.cn (J. Chen), kzen@nju.edu.cn (K. Zen), bixuehan2005@163.com (L. Li) \\ Received February 16, 2014 Accepted April 14, 2014
}

\section{ABSTRACT}

The mechanism underlying $T$ cell-mediated fulminant hepatitis is not fully understood. In this study, we investigated whether myeloid derived suppressor cells (MDSCs) could prevent the concanavalin A (ConA)induced hepatitis through suppressing $T$ cell proliferation. We observed an increase in the frequencies of MDSCs in mouse spleen and liver at early stage of ConA treatment, implicating that the MDSCs might be involved in the initial resistance of mice against ConAmediated inflammation. Subpopulation analysis showed that the MDSCs in liver of ConA-induced mice were mainly granulocytic MDSCs. Adoptive transfer of the bone marrow-derived MDSCs into ConA-treated mice showed that the MDSCs migrated into the liver and spleen where they suppressed $T$ cell proliferation through ROS pathway. In addition, the frequencies of MDSCs in mice were also significantly increased by the treatment with immune suppressor glucocorticoids. Transfer of MDSCs into the regulatory T cell (Treg)depleted mice showed that the protective effect of MDSCs on ConA-induced hepatitis is Treg-independent. In conclusion, our results demonstrate that MDSCs possess a direct protective role in $\mathrm{T}$ cell-mediated hepatitis, and increasing the frequency of MDSCs by either adoptive transfer or glucocorticoid treatment represents a potential cell-based therapeutic strategy for the acute inflammatory disease.

KEYWORDS myeloid derived suppressor cells, T cellmediated hepatitis, ROS, glucocorticoids, concanavalin A (ConA), adoptive transfer, glucocorticoid treatment

\section{INTRODUCTION}

T cell-mediated immune response plays a central role in inducing hepatocellular injury during hepatitis. Activated $T$ cells are detected in a variety of human liver diseases including autoimmune hepatitis, chronic active hepatitis B or $\mathrm{C}$, alcoholic liver diseases, hepatitis ischemia/reperfusion injury, and allograft rejection (Hong et al., 2002; Lafdil et al., 2009). T cell-mediated hepatitis can be induced in rodents by injection of concanavalin A (ConA): a lectin, originally extracted from Canavalia brasiliensis plant, which rapidly induces clinical and histological hepatitis, including up regulation of transaminase activity and $\mathrm{CD} 4^{+} \mathrm{CD} 69^{+} \mathrm{T}$ cells and down regulation of NK1.1 $1^{+}$and $\mathrm{CD}^{+}$NKT cells within $24 \mathrm{~h}$ (Hines et al., 2007). In the past two decades, major progress has been made in understanding of the molecular and cellular mechanisms underlying $T$ cell-mediated liver injury through use of this model. Evidence suggests that ConAinduced $T$ cell-mediated hepatitis is initiated and tightly controlled by interactions between multiple cell types and cytokines. Immune cells involved in ConA-induced hepatitis include $\mathrm{CD}^{+} \mathrm{T}$ cells, natural killer T cells, Tregs, Kupffer cells (Erhardt et al., 2007), neutrophils, and eosinophils (Lafdil et al., 2009). The inflammatory cytokines, IFN-y, IL-4 (Jaruga et al., 2003), and TNF-a (Wolf et al., 2001) have been shown to play an essential role in $T$ cell-mediated hepatitis. Additionally, IL-2, IL-6, IL-10, and IL-22 are also involved in ConA-induced liver injury (Radaeva et al., 2004; Erhardt et al., 2007; Takahashi et al., 2011).

Myeloid-derived suppressor cells (MDSCs) represent a heterogeneous population of immature myeloid cells including myeloid progenitors, macrophage precursors, granulocytes, and dendritic cells, which share a common 
capacity of suppressing immune responses (Gabrilovich, 2004). Murine MDSCs are characterized by the surface coexpression of $\mathrm{Gr}-1$ and $\mathrm{CD} 11 \mathrm{~b}$, and are further subdivided into two major groups: CD11 ${ }^{+} \mathrm{Ly}_{6 G^{+}}$Ly6C $^{\text {low }}$ granulocytic MDSCs and CD11b ${ }^{+}$Ly6G $^{-}$Ly6C ${ }^{\text {high }}$ monocytic MDSCs. Granulocytic MDSCs and monocytic MDSCs differ in their abilities to suppress T cell responses (Gabrilovich, 2004). Monocytic MDSCs suppress T cell proliferation by high levels of inducible nitric oxide synthase (iNOS) and Arginase 1 (ARG1), while granulocytic MDSCs mainly through high levels of reactive oxygen species (ROS) and Arginase 1 (ARG1) (Gabrilovich, 2004; Bronte and Zanovello, 2005; Gabrilovich and Nagaraj, 2009; Gabrilovich et al., 2012). MDSCs exploit various mechanisms to influence both innate and adaptive immune responses (Gabrilovich et al., 2012). In short, MDSCs can deprive $\mathrm{T}$ cells of L-cysteine and L-arginine which are essential for their growth and differentiation, generate oxidative stress that cause the loss of the TCR $\zeta$-chain, decrease CD62L expression to interfere with $T$ cell migration and viability, and induce the activation and expansion of regulatory $\mathrm{T}$ (Treg) cell populations. Under pathological conditions such as tumor growth and graft-versus-host disease, the documented accumulation of MDSCs in patients and mice suggested a critical contribution of MDSCs to these immunosuppressive conditions (Almand et al., 2001). The expansion of MDSC and its protective role in suppressing body inflammation and autoimmunity has also been observed in various pathophysiological conditions. Recent findings suggest that the accumulation of MDSCs may be related to inflammatory bowel disease (Zhang et al., 2013), type 1 diabetes (Yin et al., 2010; Xia et al., 2011), systemic lupus erythematosus, inflammatory eye disease, multiple sclerosis (Cripps and Gorham, 2011), and hepatitis $B$ and $C$ virus infection (Chen et al., 2011; Hegde et al., 2011; Tacke et al., 2012; Cai et al., 2013). Furthermore, Hegde et al. (Hegde et al., 2011) recently observed an upregulation of MDSCs subsequent to cannabidiol treatment of autoimmune liver injury. However, the direct anti-inflammatory role of MDSCs in autoimmune hepatitis remains unclear.

In the present study, we characterized the role of MDSCs in ConA-induced mouse hepatitis by detecting serum cytokines and activation markers of lymphocytes. The tissue localization of adoptive transferred MDSCs in mice under inflammatory or non-inflammatory conditions were determined. The protective effects of MDSCs on experimental hepatitis were further analyzed through increasing the frequency of MDSCs in mice through the adoptive transfer of MDSCs into mice or the glucocorticoid treatment.

\section{RESULTS}

ConA-induced hepatitis mice model

In this experiment, 8-10 weeks C57BL/6 mice were injected either with $0.9 \% \mathrm{NaCl}$ or $20 \mathrm{mg} / \mathrm{kg}$ ConA intravenously.
Following ConA administration, mice were sacrificed at different time points. Multiple evidences collectively indicated that the ConA-induced hepatitis mice model was successfully developed. H\&E staining indicated recipients of ConA had increasing liver necrosis compared to the control (Fig. 1A). Examination of serum ALT and AST activities (Fig. 1B) revealed that the ConA treatment caused a severe liver injury. The peak of ALT and AST activities was observed at the time point of $6 \mathrm{~h}$. The enhanced hepatitis injury over time was also reflected by the up regulation of serum TNF-a, IL-6, IL-12p70, and IFN-y (Fig. 1C), with the peak concentration at the time point of $6 \mathrm{~h}$, followed by a rapid decrease within $48 \mathrm{~h}$. In addition, splenic and hepatic $\mathrm{T}$ lymphocytes were rapidly activated as demonstrated by the expression of $\mathrm{CD} 9^{+}$on $\mathrm{CD}^{+}$Iymphocytes with a time dependent manner (Fig. 1D). Together, the data demonstrate that the persistence of liver injury, T cell activation, and the peak of ALT, AST, cytokines levels was $6 \mathrm{~h}$ after ConA injection, which was the time point chosen for the next experiment.

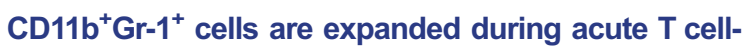
mediated hepatitis

MDSCs play an important role during benign inflammation in vivo, shaping immune responses to viral antigens, influencing antibody production, and down regulating $\mathrm{T}$ cell responses to auto-antigens (Haverkamp et al., 2011). To examine the potential role of MDSC in T cell-mediated hepatitis, the levels of $\mathrm{CD}_{11} \mathrm{~b}^{+}$cells, $\mathrm{CD} 11 \mathrm{~b}^{+} \mathrm{Gr}-1^{-}$cells, $\mathrm{CD} 11 \mathrm{~b}^{+} \mathrm{Gr}-1^{+} \mathrm{MDSC}$ (Fig. 2A) were analyzed in the spleen and liver over time. As shown in Fig. 2A, ConA injection rapidly induced accumulation of $\mathrm{CD}_{11} \mathrm{~b}^{+}$cells in the liver, and the majority of these cells are $\mathrm{CD} 11 \mathrm{~b}^{+} \mathrm{Gr}-1^{+}$MDSCs. To characterize the suppressive capacity of $\mathrm{CD} 11 \mathrm{~b}^{+} \mathrm{Gr}-1^{+}$ MDSCs from inflammatory liver, we purified MDSCs from the inflammatory liver and co-cultured them with CFSE-labeled $\mathrm{T}$ cells at different ratios. As shown in Fig. 2B, MDSCs purified from ConA-treated mouse liver strongly suppressed $T$ cell proliferation. Subpopulation analysis showed that the accumulated $\mathrm{CD} 11 \mathrm{~b}^{+} \mathrm{Gr}-1^{+}$MDSCs are mainly from the granulocytic subsets (Fig. 2C). Further, we sorted MDSC from the liver of mice treated with ConA, and found that Arginase-1 was enriched in the isolated cells (Fig. 2D). To determine whether MDSCs inhibit T cell proliferation through ROS, we used DPI as ROS inhibitor and found that DPI could significantly inhibit the function of MDSCs isolated from the ConA-treated mouse liver (Fig. 2E). These data suggest that MDSCs may regulate $T$ cell function during ConA-induced mouse hepatitis through ROS pathway.

BM-MDSCs migrate to lymphocytes-accumulated organs and exert a protective effect on ConA-induced hepatitis

To directly view the effect of transferred BM-MDSCs on attenuation of ConA-induced hepatitis in mouse model, we 

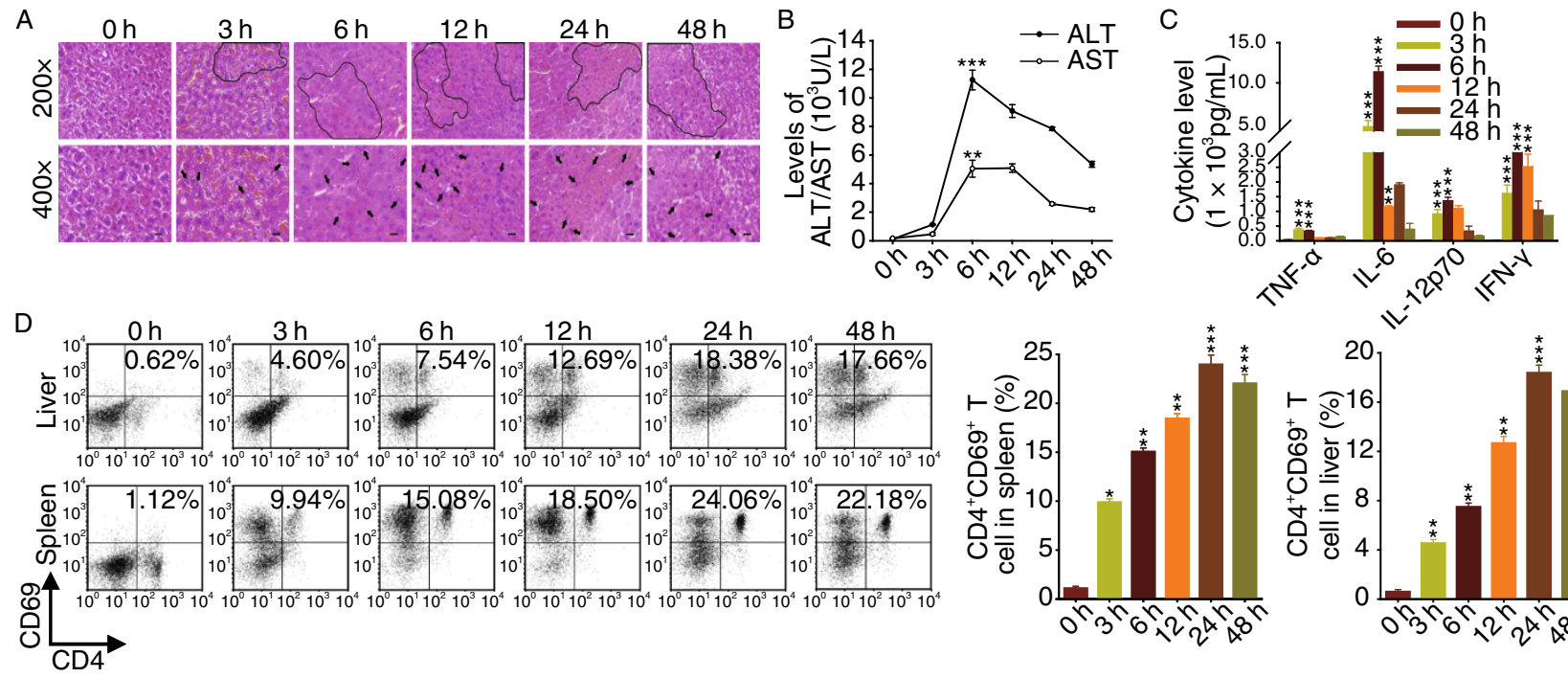

Figure 1. ConA induced mouse acute hepatitis. (A) Photomicrographs of representative mouse liver from mice treated with ConA $(20 \mathrm{mg} / \mathrm{kg}$ ) for $0,3,6,12,24$, and $48 \mathrm{~h}$ (H\&E staining, original magnification $200 \times$ and $400 \times$ ). (B) Serum ALT and AST levels at various time point post-ConA injection. (C) Circulating TNF- $\alpha$, IL-6, IFN-y, and IL-12p70 levels at various time point post-ConA injection. (D) ConA-mediated activation of mouse $\mathrm{CD}^{+} \mathrm{T}$ cells. At various time point post-ConA injection, hepatic MNC were isolated and $\mathrm{CD}^{+} \mathrm{CD} 9^{+} \mathrm{T}$ cells were analyzed. Representative scatter plots are presented (left) and the histogram (right) represents the statistical analysis of the percentages of CD69-positive $\mathrm{CD} 4{ }^{+} \mathrm{T}$ cells. All the values are shown as mean $\pm \mathrm{SEM}$. ${ }^{*} P<0.05$, ${ }^{* *} P<0.01$, and ${ }^{* \star *} P<0.005(n=5-8)$.

isolated BM from GFP transgenic mice, induced BM-MDSCs with GM-CSF and IL-6, and traced their localization in mice with ConA-induced hepatitis. Mice without ConA treatment were used as control. As shown in Fig. $3 \mathrm{~A}$ and $3 \mathrm{~B}$, at only $3 \mathrm{~h}$ after ConA injection, GFP ${ }^{+}$BM-MDSCs were readily detected in BM, spleen, and liver tissues, but not visible in $\mathrm{BM}$, spleen, and liver of control mice, suggesting the homing of exogenous MDSCs is modulated by inflammatory condition. Furthermore, as shown in Fig. 3C, the transferred BMMDSCs significantly increased the frequency of $C D 11 \mathrm{~b}^{+} \mathrm{Gr}-1^{+}$ MDSCs in mouse liver. Adoptive transfer of BM-MDSCs also markedly decreased the population of $\mathrm{CD}^{+} \mathrm{CD}^{+} 9^{+} \mathrm{T}$ cells. These results suggest that the transferred BM-MDSCs could migrate to certain organs where lymphocytes accumulated under inflammatory condition.

To better understand the effect of MDSCs on the suppression of T cell-mediated hepatitis development, we compared ConA-induced hepatitis with or without exogenous transfer of BM-MDSCs in different number. Examination of liver pathology showed massive necrosis in mice without BM-MDSCs transfer, but not in mice transferred with BMMDSCs (Fig. 3D). The levels of AST and ALT were dramatically decreased in serum of mice transferred with BMMDSCs (Fig. 3E). Since TNF- $\alpha$, IL-6, IL-12p70, and IFN- $\gamma$ have been shown to play an important role in T cell-mediated hepatitis (Lafdil et al., 2009), we compared the serum TNF-a, IL-6, IL-12p70, and IFN-y levels in mice with or without BM-
MDSCs transfer. As expected, the ConA-induced elevation of TNF- $\alpha, \quad I L-6, I L-12 p 70$, and IFN- $\gamma$ levels significantly attenuated in BM-MDSCs-transferred mice compared to those of non BM-MDSCs-transferred mice (Fig. 3F). From the concentration gradient we could also find that the effect of BM-MDSCs on protection of ConA-induced injury was dose-dependent. When the number of MDSC was less than $5 \times 10^{5}$, the protection effect was disappeared in ConAinduced mice. Besides, there was also no significant difference of liver damage, level of ALT/AST and cytokine between only MDSC and vehicle control, suggesting that MDSCs themselves do not damage liver cells.

\section{Glucocorticoids protect mice from ConA-induced hepatitis through expanding MDSC}

Glucocorticoids (GC) provide the most effective anti-inflammatory treatments for many inflammatory and immune diseases, including asthma, rheumatoid arthritis, inflammatory bowel disease, and autoimmune diseases (Barnes and Adcock, 2009). Systemically active conventional corticosteroids have played a significant role in the induction of remission in autoimmune liver diseases, liver transplantation, and virus induced hepatitis (Ducci and Katz, 1952; Czaja et al., 1984; Fujiwara et al., 2010). Recent study by Varga et al. (Varga et al., 2008) suggested that the GC treatment might induce an activated, anti-inflammatory 
A
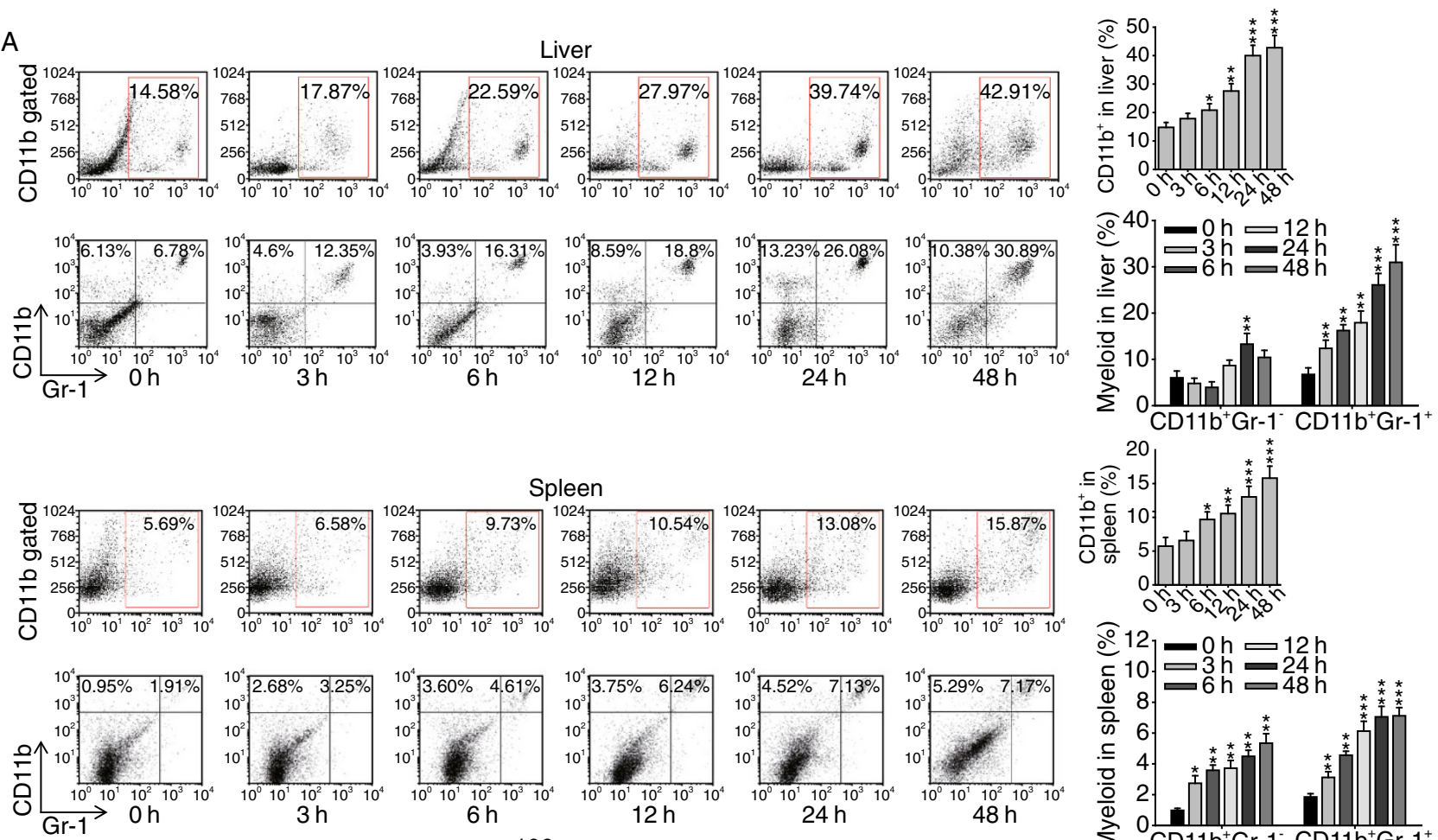

Spleen
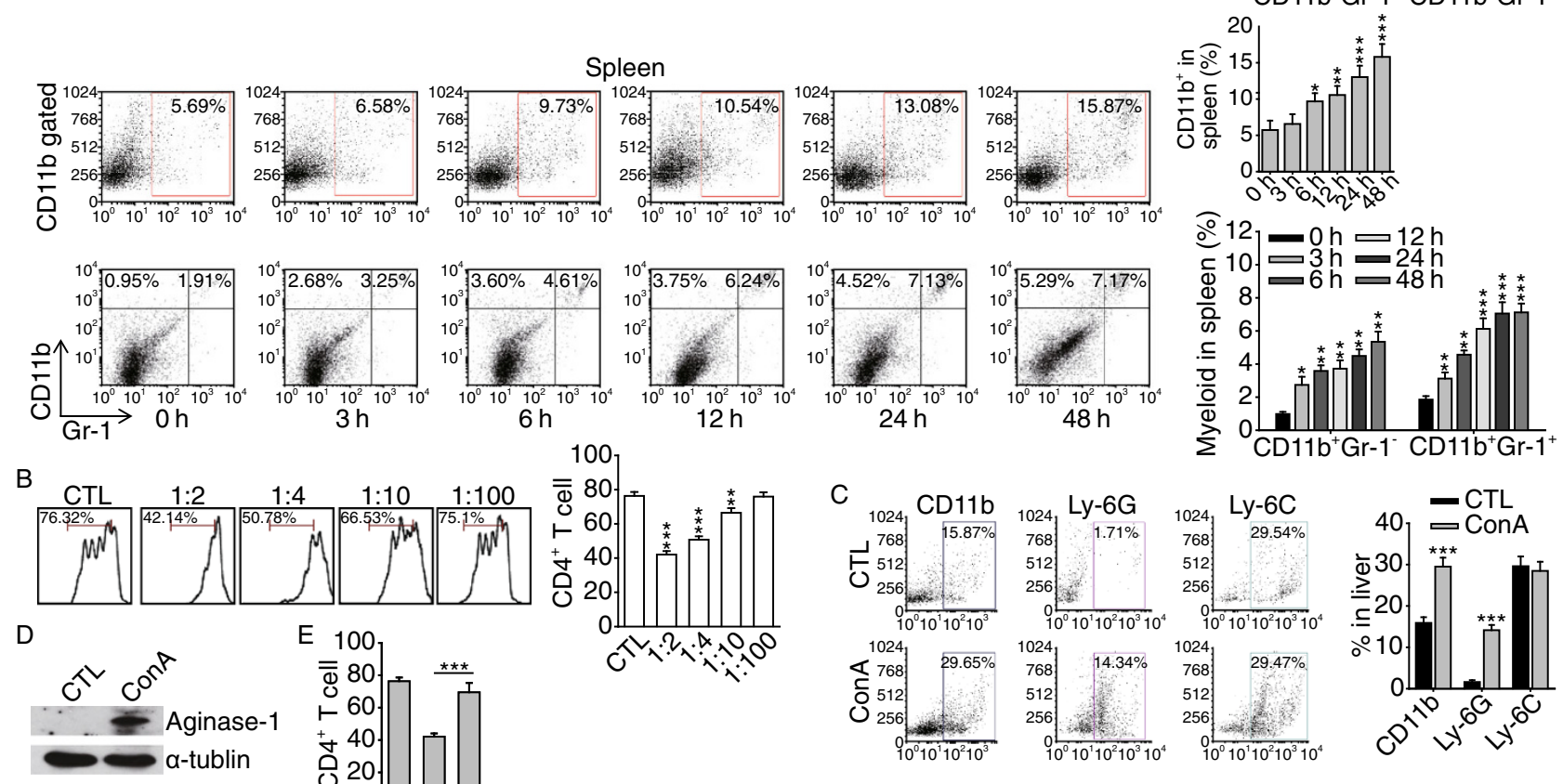

E 100

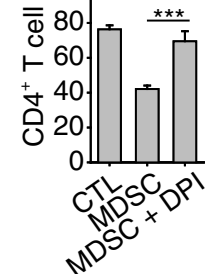

C
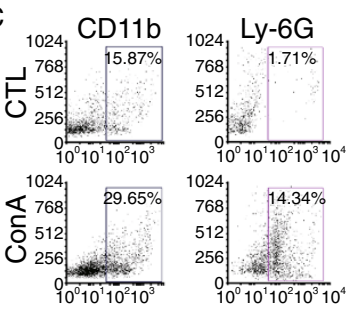
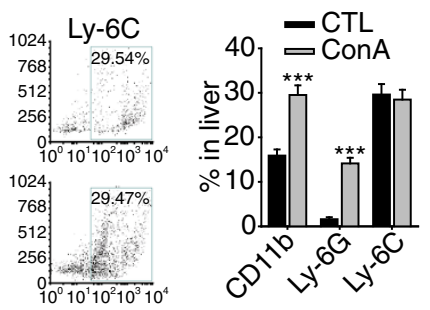

Figure 2. Mouse MDSCs were expanded and activated following ConA treatment. (A) Analysis of CD $11 b^{+}$cells, CD $11 b^{+}$Gr-1 ${ }^{-}$ cells, and CD $11 \mathrm{~b}^{+} \mathrm{Gr}-1^{+}$MDSCs in ConA-treated mouse liver and spleen. Representative scatter plots (left) are presented and the histogram (right) represents the statistical analysis of the percentages of CD11 ${ }^{+}$cells, CD $11 b^{+}$Gr $-1^{-}$cells, and CD11 $b^{+}$Gr- $1^{+}$ MDSCs. (B) Inhibition of mouse liver MDSCs on T cell proliferation. MDSCs were isolated from ConA-treated mice and the inhibition assay was performed at various MDSC vs. T cell ratio. The histogram (lower panel) represented the statistical analysis of CD4 ${ }^{+} \mathrm{T}$ cell proliferation. (C) Analysis of CD11 $\mathrm{b}^{+}$Ly6G-Ly6C ${ }^{\text {high }}$ monocytic MDSCs and CD11 $\mathrm{b}^{+}$Ly6G ${ }^{+}$Ly6C ${ }^{\text {low }}$ granulocytic MDSCs from the ConA-treated mouse liver. Normal mice were used as control (CTL). (D) Protein level of Arginase-1 were detected in MDSCs of ConA-induced mice liver. (E) Inhibition of T cell proliferation by MDSCs isolated from the liver of ConA-treated mice at the ratio of 1:2 (MDSC vs. T cell) with or without DPI. All the values are shown as mean \pm SEM. ${ }^{*} P<0.05,{ }^{* \star} P<0.01$, and ${ }^{* *} P<0.005(n=5-8)$.

monocyte subset in mice that resembles myeloid-derived suppressor cells. In the present study, we treated mice with synthetic GC such as dexamethasone (DEX) after the process of ConA-induced experimental hepatitis. The results showed that DEX treatment strongly increased the fre- quency of $\mathrm{CD} 11 \mathrm{~b}^{+} \mathrm{Gr}-1^{+} \mathrm{MDSC}$ in mice spleen and liver (Fig. 4A). Accordingly, the populations of $\mathrm{CD}^{+} \mathrm{CD}^{+} 9^{+} \mathrm{T}$ cells in mouse spleen and liver were strongly down regulated by DEX treatment (Fig. 4C). MDSCs isolated from liver of mice treated with DEX also have the ability to inhibit $\mathrm{T}$ cell prolif- 

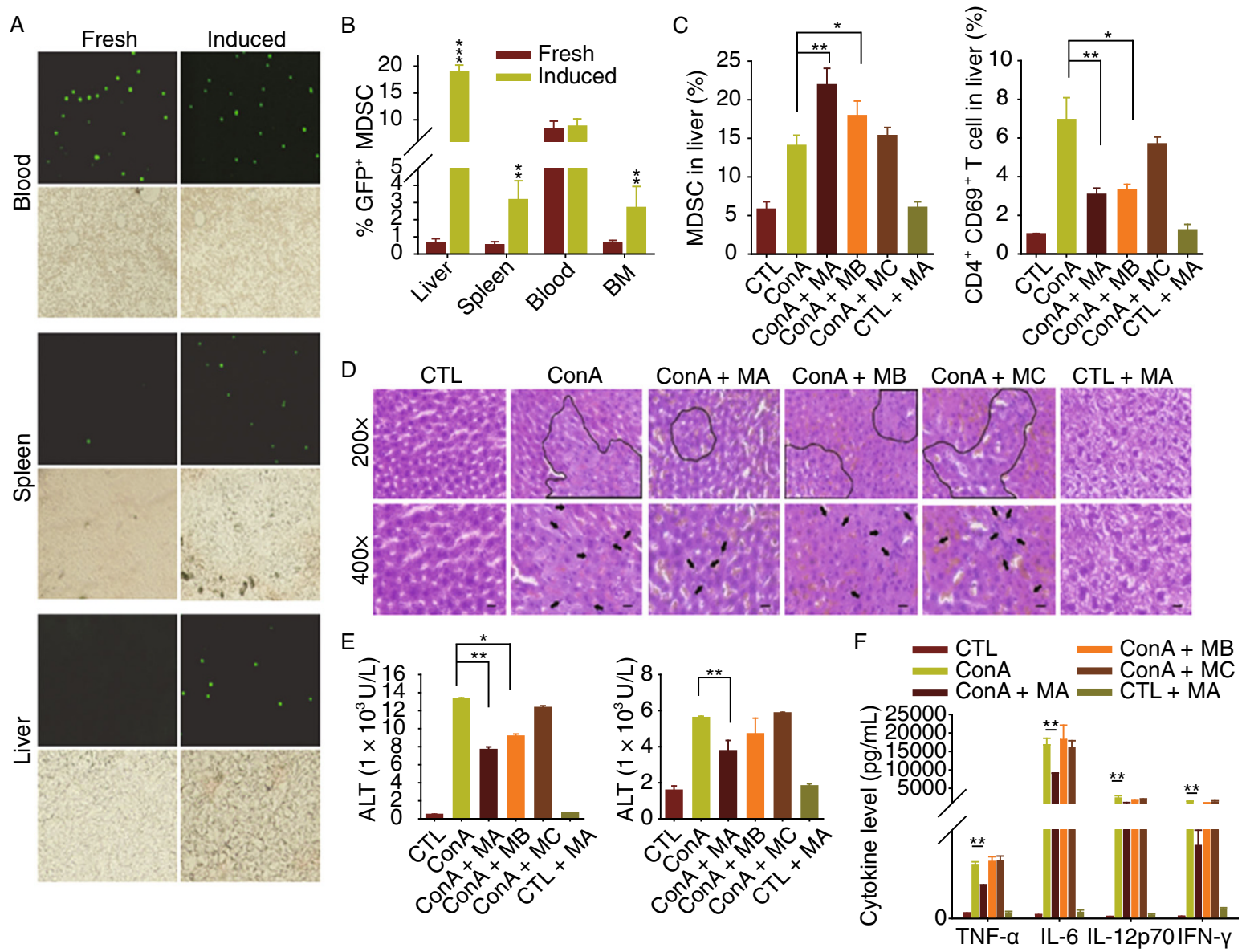

Figure 3. Adoptively transferred MDSCs attenuated ConA-induced mouse hepatitis. (A) Tracing of adoptively transferred MDSCs in mice with or without ConA $(20 \mathrm{mg} / \mathrm{kg}$ ) treatment. GFP-labeled BM-MDSCs were prepared from GFP transgenic mice and then injected into C57BL/6 mice intravenously. At the same time, mice were treated with or without ConA. (B) Analysis of the percentages of GFP-labeled BM-MDSCs in ConA-treated mouse liver, spleen, blood, and BM. (C) Frequencies of MDSCs and CD4 ${ }^{+}$ $\mathrm{CD}^{+} 9^{+} \mathrm{T}$ cells in mouse liver. Different concentrations of BM-MDSCs (MA, MB, and MC represented $5 \times 10^{6}, 5 \times 10^{5}$, and $5 \times 10^{4}$ cells of MDSCs, respectively, the same as in panels D-F) were transferred intravenously to mice with ConA treatment. (D) Photomicrographs of representative liver sections from mice treated with ConA and MDSCs (H\&E staining, original magnification, 200x and 400×). (E) Serum levels of ALT and AST in mice treated with ConA and BM-MDSCs. (F) Levels of circulating TNF- $\alpha$, IL-6, IFN- $\gamma$, and IL-12p70 in mice treated with ConA and BM-MDSCs. Values are shown as mean \pm SEM. ${ }^{*} P<0.05,{ }^{* *} P<0.01$ and ${ }^{* * *} P<0.005$ $(n=5-8)$.

eration in vitro (Fig. 4D). Importantly, there is no significantly difference of macrophages between the group of vehicle, ConA, ConA and DEX (Fig. 4B), suggesting that CD11b $\mathrm{b}^{+} \mathrm{Gr}-1^{+}$ MDSCs are the main functional cells induced by DEX.

Next, we compared the ConA-induced mouse hepatitis with or without DEX treatment. As shown in Fig. 4E-G, DEX treatment strongly attenuated the ConA-induced hepatitis in mice, accompanied with fewer necrotic liver cells (Fig. 4E), lower activities of ALT and AST (Fig. 4F). Compared to mice treated with ConA alone, mice treated with ConA and DEX also displayed a significant lower level of serum TNF- $\alpha$, IL-6, IL-12p70, and IFN-Y (Fig. 4G). These results implicate that the protection of DEX against ConA-induced hepatitis may be dependent on the induction of MDSCs.

\section{MDSCs protect ConA-induced mice hepatitis independent of Tregs}

Tregs have been reported as one of the cells targeted by MDSCs (Pan et al., 2008). To investigate the relationship between MDSCs and Tregs in our model, we transiently depleted Tregs by injecting rat anti-mouse CD25 antibody (Yu et al., 2010). As shown in Fig. 5A, Tregs in mouse spleen were effectively depleted by CD25 antibody. Constructing 

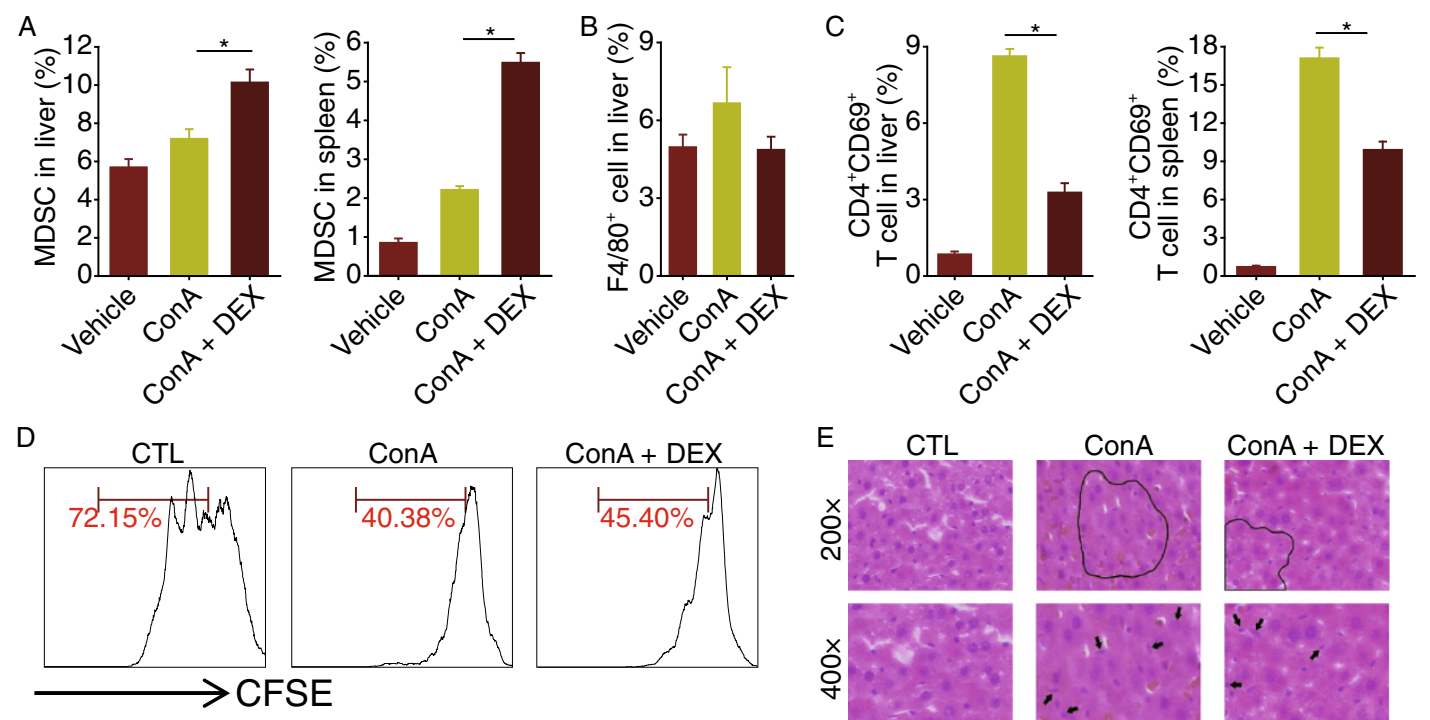

E CTL
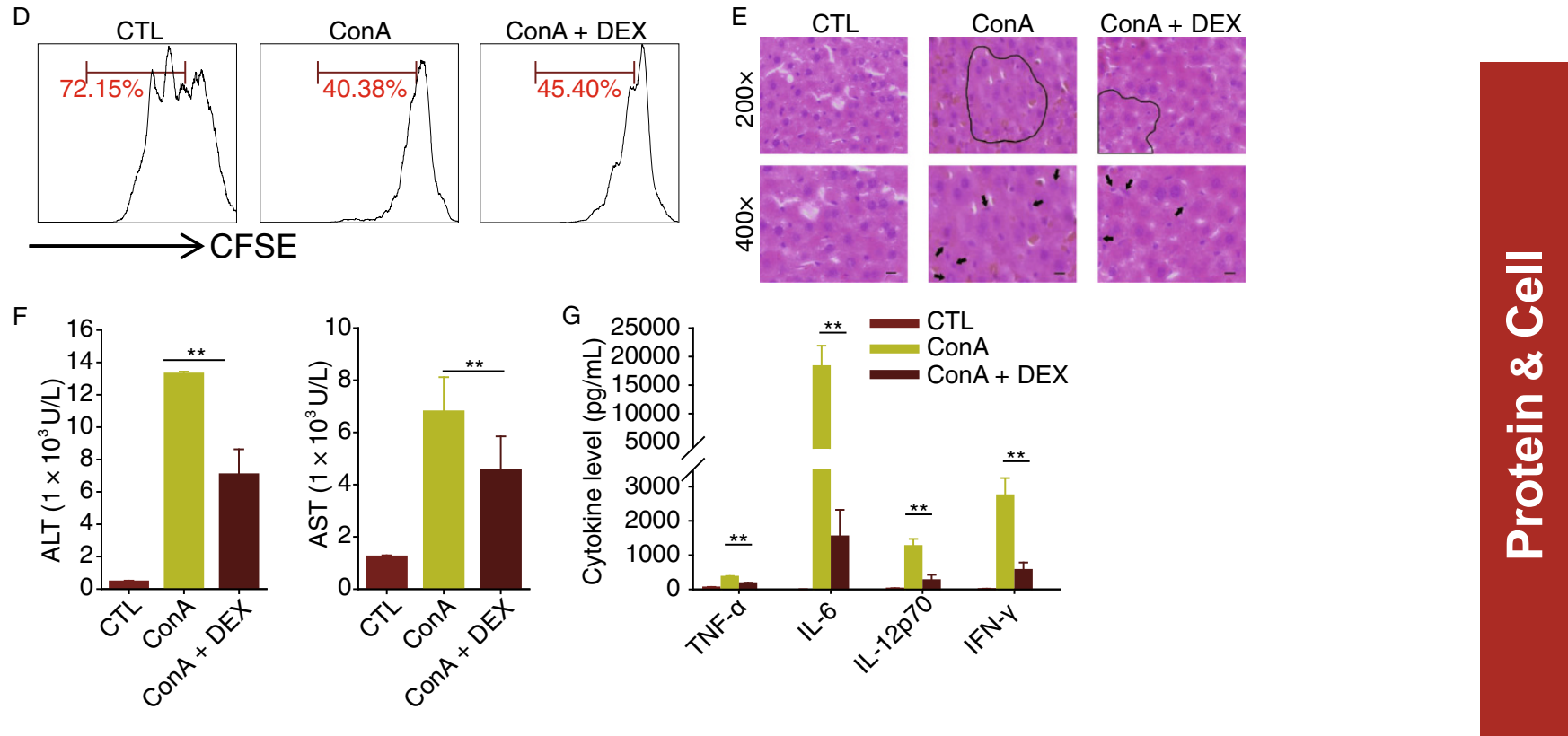

Figure 4. Dexamethasone treatment protected mice from ConA-induced hepatitis through expanding MDSCs. (A) The levels of MDSCs in liver and spleen of ConA-treated mice that were injected with or without DEX. Mice were injected intraperitoneally with dexamethasone (DEX, $1 \mathrm{mg} / \mathrm{kg}$ bodyweight) and ConA $\left(20 \mathrm{mg} / \mathrm{kg}\right.$ ). (B) The levels of $\mathrm{F} 4 / 80^{+}$macrophages in liver of ConA-treated mice that were injected with or without DEX. (C) The levels of CD4 ${ }^{+} \mathrm{CD} 69^{+} \mathrm{T}$ cells in liver and spleen of ConA-induced mice that were injected with or without DEX. (D) The inhibition of T cell proliferation by MDSCs isolated from mouse livers that were treated with or without DEX. (E) The representative H\&E staining of liver sections of ConA-treated mice that were injected with or without DEX. (F) Serum ALT and AST levels in ConA-treated mice that were injected with or without DEX. (G) Circulating TNF- $\alpha$, IL-6, IFN- $\gamma$, and $\mathrm{IL}-12 \mathrm{p} 70$ levels in ConA-treated mice that were injected with or without DEX. Values are shown as mean \pm SEM. ${ }^{*} P<0.05$, ${ }^{* *} P<0.01$, and ${ }^{* * *} P<0.005(n=5-8)$.

ConA-induced hepatitis model on Treg-depleted mice, we found that depletion of Tregs upregulated $\mathrm{CD} 4^{+} \mathrm{CD} 69^{+} \mathrm{T}$ cells in the liver and spleen (Fig. 5B). Furthermore, after transferring the BM-MDSCs into Treg-depleted mice which were also treated with ConA, we found that exogenous BMMDSCs significantly down regulated the $\mathrm{CD} 4^{+} \mathrm{CD} 69^{+} \mathrm{T}$ cells in the liver and spleen. Examination of mouse liver tissues showed severer necrosis in Treg-depleted mice than mice without depletion of Tregs. As shown in Fig. 5C, transfer of BM-MDSCs could alleviate liver injury significantly. As expected, the levels of AST and ALT (Fig. 5D) or TNF- $\alpha$, IL-6, IL-12p70, and IFN-y (Fig. 5E) were dramatically decreased in the serum of mice with BM-MDSCs transfer compared to those of mice without BM-MDSCs transfer. These results implicate that MDSC can protect mouse liver from ConAmediated injury in a Treg-independent manner.

\section{DISCUSSION}

T cell activation in HCV, HBV, drug intoxication, and alcoholic liver diseases mediated hepatitis has been shown to play a central role in hepatocellular injury. For example, in chronic $\mathrm{HBV}$ and $\mathrm{HCV}$ infection, although the viruses themselves are not cytopathogenic, activated $\mathrm{CD} 8^{+} \mathrm{T}$ cells kill viral infected hepatocytes, while activation of $\mathrm{CD}^{+}{ }^{+} \mathrm{T}$ cells produces inflammatory cytokines and intern controls $\mathrm{CD}^{+} \mathrm{T}$ cell cytotoxicity contributing to the progression of liver disease (Rehermann, 2000; Rosen et al., 2002; Chang, 2003). It has 
A
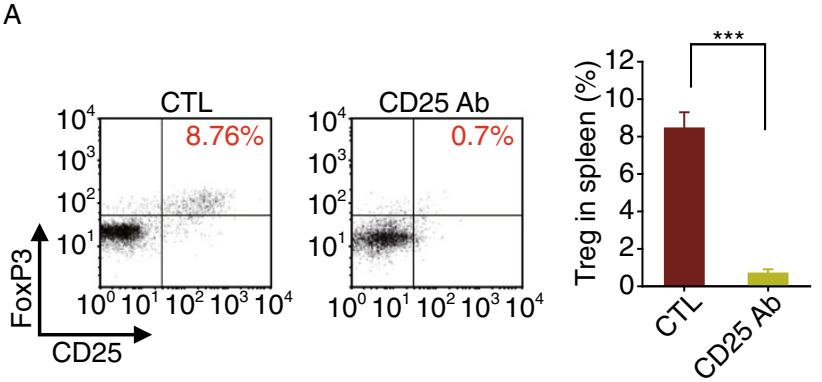

$\mathrm{B}$
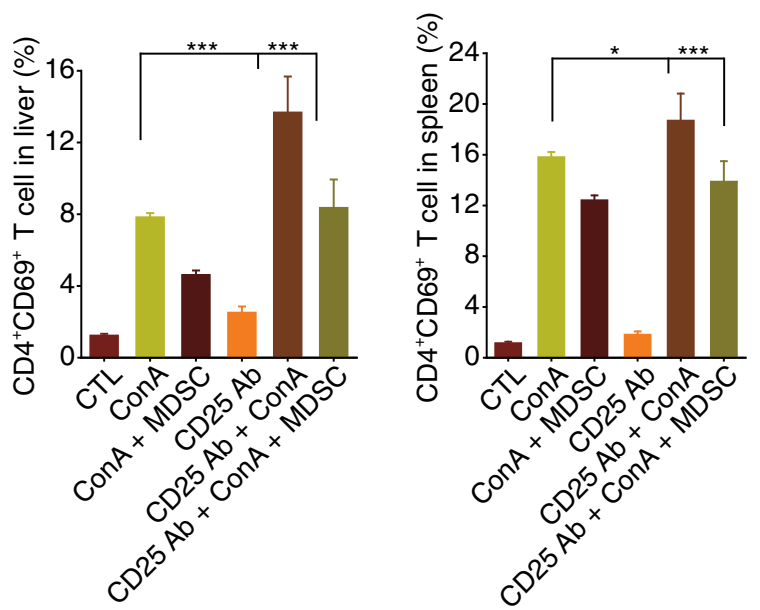

C
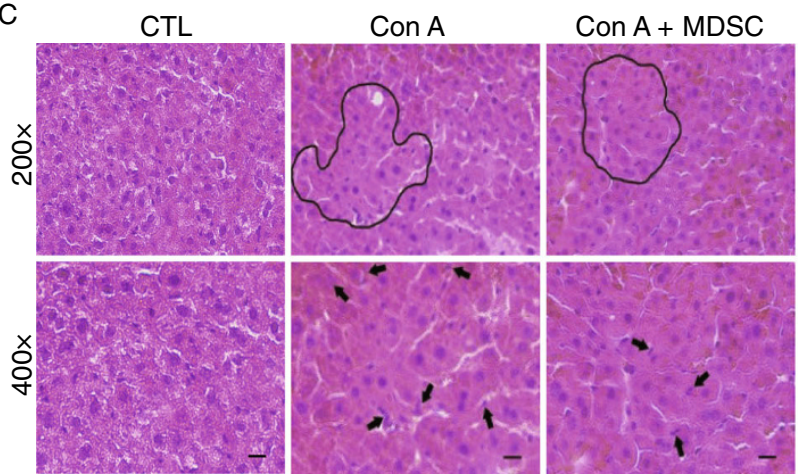

D
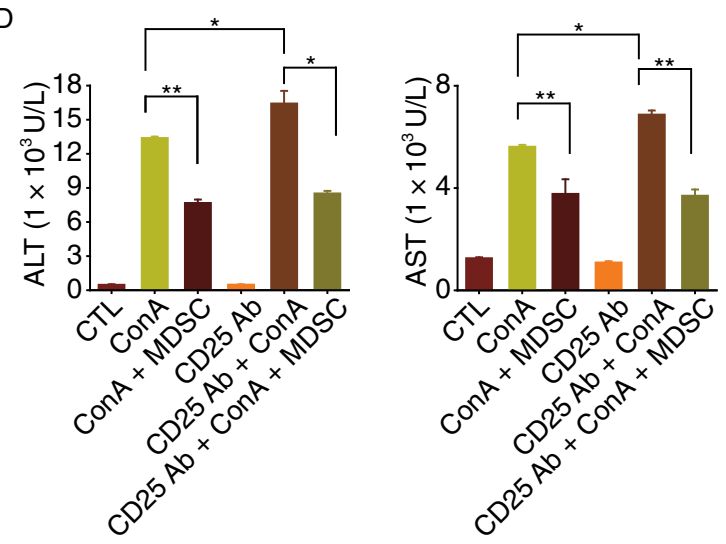

E
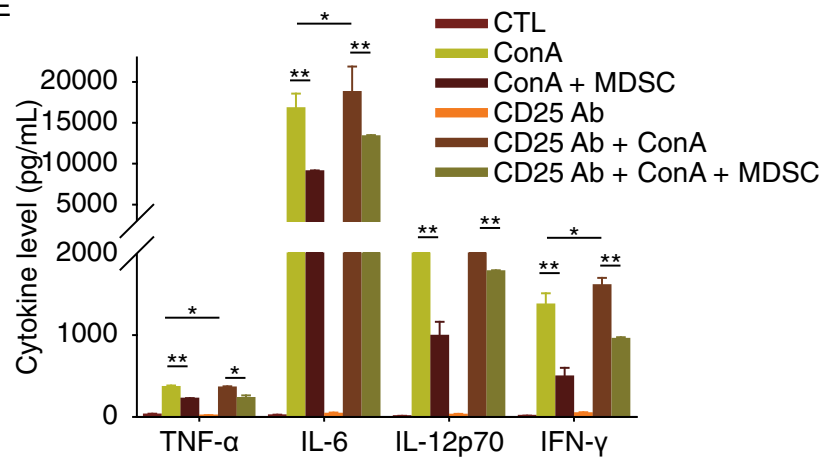

CD25 Ab
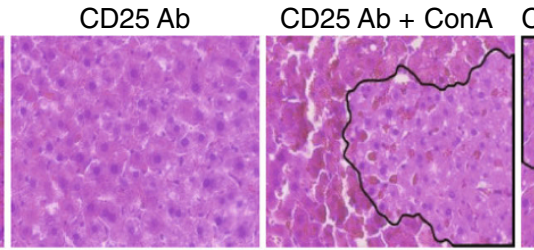

CD25 Ab + ConA + MDSC

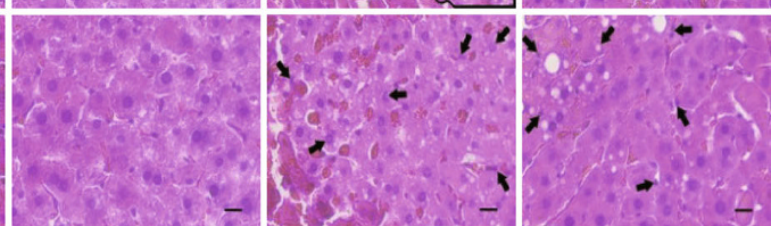

Figure 5. MDSCs protected ConA-induced mice hepatitis in a Treg-independent manner. (A) Depletion of Tregs in mouse spleen by treating mice with rat anti-mouse CD25 antibody (CD25 Ab) (left). The histogram (right) represented the statistical analysis of the percentages of Tregs in spleen. (B) Analysis of the effect of Treg depletion on ConA-treated mice. The percentages of $\mathrm{CD}^{+} \mathrm{CD}^{+} 9^{+} \mathrm{T}$ cells in liver and spleen were presented. (C) Photomicrographs of representative H\&E staining of mouse liver sections $6 \mathrm{~h}$ post-ConA injection (original magnification, 200x and 400x). During ConA treatment, control and Treg-depleted mice were transferred with or without BM-MDSCs. (D) Serum levels of ALT and AST in ConA-treated control or Treg-depleted mice with or without adoptive transfer of BM-MDSCs. (E) Levels of circulating TNF- $\alpha$, IL-6, IFN- $\gamma$, and IL-12p70 in ConA-treated control or Tregdepleted mice with or without adoptive transfer of BM-MDSCs. Values are presented as mean \pm SEM. ${ }^{\star} P<0.05$, ${ }^{\star *} P<0.01$, and ${ }^{* * *} P<0.005(n=5-8)$.

been well documented that the T cell-mediated hepatitis is controlled by the interactions between cytokines and multiple cells (Tiegs, 2007). Previous studies have shown that MDSCs may be involved in down regulation of immune responses through inhibiting T cell not only in tumor situation, but also in a variety of allogeneic transplant models, autoimmune diseases, and other inflammatory diseases (Garcia et al., 2010; Yin et al., 2010). Chou and co-workers (Chou et al., 2011) discovered that hepatic stellate cells can promote the generation of MDSCs with significant immune inhibitory activity in vitro and in vivo, suggesting a great clinical application potential of MDSC. 
The immune suppressor activity of MDSC has been associated with high Arginase-1 and iNOS activity (Greten et al., 2011). Both Arginase-1 and iNOS are highly expressed in MDSCs of tumor bearing mice. iNOS generates nitric oxide (NO) to suppress T cell function via utilizing $L$-arginine, while Arginase-1 leads to CD3 $\zeta$-chain downregulation and cell cylce arrest through upregulating the expression of cyclin D3 and cdk4 (Rodriguez et al., 2007; Gabrilovich and Nagaraj, 2009). It is reported that novel mechanism of T cell tolerance is associated with reactive oxygen species (ROS) and peroxynitrite (Nagaraj et al., 2007). Tacke and coworkers (Tacke et al., 2012) reported that hepatitis C virus could induce myeloid suppressor cells to suppress T-Cell responses through the production of ROS. Cai et al. (Cai et al., 2013) revealed that a significant correlation between MDSC levels and HCV disease progression, and MDSCs could suppress $\mathrm{T}$ cell function in an Arginase-1-dependent manner. Ilkovitch et al. (Ilkovitch and Lopez, 2009) first confirmed that splenic MDSCs isolated from tumor bearing mice can migrate to and accumulate in the liver, suggesting that tumor induced MDSCs may play an immunosuppressive role in the liver. In the present study, using an established model of ConA-induced hepatitis, we demonstrate that the MDSCs are involved in T cell-mediated liver injury and that MDSC-mediated suppression of early $\mathrm{CD} 4^{+} \mathrm{CD} 9^{+} \mathrm{T}$ cells proliferation can protect mice from ConA-induced hepatitis through ROS pathway.

Glucocorticoids have been the most common immunosuppressants used in the treatment of T cell-mediated liver disease (Suda et al., 2003). The role of these agents in liver diseases and liver transplantation has been well documented. Previous studies have reported that the use of glucocorticoids in the early period of severe hepatitis may prevent the necrosis of liver cells and provide a possibility of liver regeneration (Czaja et al., 1984). Recently, the use of glucocorticoids to treat HBV-related liver failure has become much safer because of the new generation of nucleoside analogs, proton pump inhibitors, and effective infection control measures. Although glucocorticoids have long been used to treat the patients with liver dysfunction, the mechanism underlying the profound effect of glucocorticoids on inflammation remains incompletely understood. Previous studies suggested that the glucocorticoids served in multiple capacities by decreasing inflammation and suppressing immune function by interfering with the function of $\mathrm{T}$ lymphocytes, reducing the recruitment of monocytes and macrophages, inhibiting the function of immune competent cells, and inhibiting the release of inflammatory cytokines (Elenkov and Chrousos, 1999; Franchimont et al., 2000; Schleimer et al., 2009). By studying the subpopulation of steroidresistant $\mathrm{CD}^{+}{ }^{+} \mathrm{T}$ cells, Lee et al. (Lee et al., 2007) showed that the steroid resistance of $T$ cells was associated with CD25 expression and CD $4^{+}$CD $25^{\text {int }}$ cells, which were highly resistance to DEX treatment. In the present study, we demonstrated that the DEX could directly promote the generation of MDSCs from bone marrow cells. Increasing the frequency of MDSCs by glucocorticoids might serve as a novel mechanism underlying the suppressive effect of glucocorticoids on various chronic inflammatory and autoimmune diseases.

In summary, our study demonstrates for the first time that MDSCs, derived from adoptively transfer or directly induction by glucocorticoids treatment, can effectively protect mice from ConA-induced hepatitis through downregulating early $\mathrm{T}$ cell proliferation and inflammatory responses. Our finding also provides a novel MDSC-based therapeutic strategy in controlling $\mathrm{T}$ cell-mediated hepatitis.

\section{MATERIALS AND METHODS}

\section{Reagents}

Concanavalin A (ConA), dexamethasone, and DPI were purchased from Sigma-Aldrich (St. Louis, MO). Murine IL-6 and GM-CSF cytokines were from PEPROTECH (Rocky Hill, NJ). PerCP/Cy5.5conjugated anti-mouse (Gr-1), APC-conjugated anti-mouse CD3, and $\mathrm{PE}$-conjugated anti-mouse $\mathrm{CD} 11 \mathrm{~b}$ were purchased from Biolegend (San Diego, CA). FITC-conjugated rat anti-mouse CD4, APC-conjugated anti-mouse $\mathrm{CD69}$, and mouse regulatory $\mathrm{T}$ cell Staining Kit were purchased from eBioscience (San Diego, CA). Purified NA/LE rat anti-mouse CD25 was purchased from BD Pharmingen. Collagenase Type II and DNase I were purchased from Gibco by life technologies (Carlsbad, CA). Rabbit polyclonal antibody to Arginase-1 was purchased from Cell Signaling Technology (Danvers, MA) and mouse monoclonal antibody to alpha tubulin was purchased from Abcam (Cambridge, MA).

\section{Animals}

Eight-week-old male C57BL/6 mice were obtained from the Nanjing University Animal Center (Nanjing, China). Green fluorescent protein (GFP) transgenic mice were purchased from the Jackson Laboratory (Bar Harbor, ME). All Animal maintenance and experimental procedures were carried out in accordance with the US National Institute of Health Guidelines for Use of Experimental Animals and approved by the Animal Care Committee of the Nanjing University.

\section{Adoptive transfer of BM-MDSC and dexamethasone treatment}

The BM-derived MDSCs were obtained as described previously (Bronte and Zanovello, 2005). Briefly, the cells were planted into the dishes using RPMI 1640 medium supplemented with $2 \mathrm{mmol} / \mathrm{L}$ L-glutamine, $10 \mathrm{mmol} / \mathrm{L}$ HEPES, $20 \mu \mathrm{mol} / \mathrm{L}$ 2-mercaptoethanol, $150 \mathrm{U} / \mathrm{mL}$ streptomycin, $200 \mathrm{U} / \mathrm{mL}$ penicillin, 10\% FBS and stimulated with combinations of GM-CSF $(40 \mathrm{ng} / \mathrm{mL})$ and IL-6 $(40 \mathrm{ng} / \mathrm{mL})$. Cells were cultured at $37^{\circ} \mathrm{C}$ in $5 \% \mathrm{CO}_{2}$-humidified atmosphere for 4 days. $5 \times 10^{6}$ BM-MDSCs were injected intravenously accompanied ConA injection. In separate experiment, dexamethasone (1 $\mathrm{mg}$ per $\mathrm{kg}$ bodyweight) was injected intraperitoneally accompanied ConA injection. 


\section{Depletion of Tregs}

To deplete Tregs, mice were injected intraperitoneally $0.5 \mathrm{mg}$ purified rat anti-mouse CD25 or isotype control, according to the method of Yu et al. (Yu et al., 2010).

Isolation of liver MNC and spleen cell preparation

Liver mononuclear cells (MNC) were isolated and purified by the method of Richman et al. (Richman et al., 1979), combined with Percoll density separation ( $\mathrm{Li}$ et al., 2009). Briefly, livers were mechanically disrupted into $1 \mathrm{~mm}^{3}$ pieces and digested for $45 \mathrm{~min}$ at $37^{\circ} \mathrm{C}$ with $0.05 \%$ collagenase Type II and $0.001 \%$ DNase I in RPMI 1640 medium. After filtered with $70 \mu \mathrm{m}$ nylon cell strainer (BD Falcon) and centrifuged for $5 \mathrm{~min}$ at $50 \times \mathrm{g}$. Supernatants were centrifuged for 5 min at $400 \times g$, pellet was washed with HBSS without $\mathrm{Ca}^{2+}$ and $\mathrm{Mg}^{2+}$. MNC resuspended in 40\% Percoll, were gently overlayed onto $70 \%$ Percoll and centrifuged for $20 \mathrm{~min}$ at $750 \times \mathrm{g}$. Purified MNC were collected from the interface for further analysis of hepatic MDSCs and T cells. Spleens were collected in sterile HBSS without $\mathrm{Ca}^{2+}$ and $\mathrm{Mg}^{2+}$, grinded, and filtered. After erythrocytes were depleted, purified splenic cells were collected for further flow analysis.

\section{Flow cytometric analysis}

Flow cytometry was conducted using BD FACScalibur device and analyzed with FCS express V3. After washing with Hank's buffer devoid of $\mathrm{Ca}^{2+}$ and $\mathrm{Mg}^{2+}$ (HBSS), $5 \times 10^{5}$ cells from liver and spleen were blocked using $1 \% \mathrm{BSA}$ at $4^{\circ} \mathrm{C}$ for $30 \mathrm{~min}$. CD4, CD69, CD11b, and $\mathrm{Gr}-1$ antibodies were added for incubation in another $30 \mathrm{~min}$ at $4^{\circ} \mathrm{C}$. Tregs were analyzed by using mouse regulatory $\mathrm{T}$ cell Staining Kit (eBioscience).

\section{T cell proliferation}

In order to obtain high purity MDSCs from liver, cell isolation kit (Miltenyi Biotec., Bergisch Gladbach, Germany) was used according to manufacturer's instructions. For $\mathrm{T}$ cell proliferation assay, the splenocytes were firstly separated with lymphocyte separation medium. Lymphocytes were labeled with CFSE according to manufacturer's instructions (Invitrogen). CFSElabeled lymphocytes were stimulated with ConA, and lymphocytes were co-cultured at 2:1, 4:1, 10:1, or 100:1 ratio with induced liver MDSCs in 96-well flat bottom plates. For MDSC inhibition assay, an inhibitor of NADPH oxidase, diphenyliodonium chloride (DPI, Sigma-Aldrich) was used as previously reported (Cheng et al., 2013). In brief, $10 \mu \mathrm{mol} / \mathrm{L}$ DPI was used in co-cultured MDSC and lymphocytes. After 4 days, cells were stained with CD3 antibody, and CFSE signal of gated lymphocytes was analyzed. The extent of cell proliferation was quantified by the FCS expressing V3.

\section{Western blot analysis}

MDSCs derived from mice livers were lysed in lysis buffer containing $100 \mathrm{mmol} / \mathrm{L}$ Tris ( $\mathrm{pH} 7.5), 150 \mathrm{mmol} / \mathrm{L} \mathrm{NaCl}, 1 \%$ Triton X-100, protease inhibitor cocktail of $\mathrm{PI}$ and PMSF. The antigens were visualized using the ECL plus detection system (Amersham Pharmacia Biotech). Normalization was performed by blotting the same samples with the anti-alpha tubulin antibody.

\section{Assay for serum aminotransferase activity}

Mice were sacrificed after ConA injection for different time and blood samples were collected in $1.5 \mathrm{~mL}$ tubes. After centrifugation at 2,500 rpm for $15 \mathrm{~min}$, serum was recovered and immediately frozen at $-70^{\circ} \mathrm{C}$. Serum alanine aminotransferase (ALT and AST) activities were determined by using the serum aminotransferase test kit (Nanjing Jiancheng Bioengineering Institute, China) according to the manufacturer's instructions.

\section{Measurement of serum cytokine levels}

Whole blood was collected without anticoagulant and the serum was isolated by centrifugation. Serum levels of TNF- $\alpha$, IFN- $\gamma$, IL- 6 , and IL-12p70 were determined using ELISA kits (R\&D) according to the manufacturer's instruction. The absorbance was measured with a wavelength correction (A450 $\mathrm{nm}$ ) with a microplate reader (BioRad).

\section{Histopathology}

Livers from individual mice were cut into $2 \times 4 \times 4 \mathrm{~mm}^{3}$ sections, fixed in $4 \%$ paraformldehyde and embedded in paraffin. $5 \mu \mathrm{m}$ slices were then cut at various depths in the tissue sections, stained with hematoxylin-eosin (H\&E) and examined under light microscopy to determine the level of inflammation.

\section{Tracing of BM-derived MDSCs in mice induced with ConA}

Fluorescent BM-MDSCs were obtained from GFP transgenic mice following GM-CSF and IL-6 induction and injected intravenously $\left(5 \times 10^{6} /\right.$ per mouse) $1 \mathrm{~h}$ before ConA injection. For tracing the location of fluorescently labeled BM-MDSCs, mice were sacrificed $3 \mathrm{~h}$ after injection. The fluorescence of blood was analyzed by fluorescence microscope directly. The spleens and livers were removed for frozen section. Then, fluorescent BM-MDSCs were analyzed by fluorescence microscope.

\section{Statistical analysis}

Data shown are presented as mean \pm SEM of at least three independent experiments; differences are considered statistically significant at $P<0.05$ by Student's $t$-test.

\section{ACKNOWLEDGEMENTS}

This work was supported by grants from the National Basic Research Program (973 Program) (Nos. 2012CB517603 and 2011CB504803), the National Natural Science Foundation of China (Grant No. 31301061), the Natural Science Foundation of Jiangsu Province (No. BK2011013 and BK20130564), and the Specialized Research Fund for the Doctoral Program of Higher Education (20130091120037). 


\section{ABBREVIATIONS}

ARG1, Arginase 1; ConA, concanavalin A; DPI, diphenyliodonium chloride; iNOS, inducible nitric oxide synthase; MDSCs, myeloid derived suppressor cells; MNC, liver mononuclear cells; ROS, reactive oxygen species; Treg, regulatory $\mathrm{T}$ cell.

\section{COMPLIANCE WITH ETHICS GUIDELINES}

Wenli Diao, Fangfang Jin, Chen-Yu Zhang, Jiangning Chen, Ke Zen and Limin Li declare that they have no conflict of interest.

All institutional and national guidelines for the care and use of laboratory animals were followed.

\section{OPEN ACCESS}

This article is distributed under the terms of the Creative Commons Attribution License which permits any use, distribution, and reproduction in any medium, provided the original author(s) and the source are credited.

\section{REFERENCES}

Almand B, Clark JI, Nikitina E, van Beynen J, English NR, Knight SC, Carbone DP, Gabrilovich DI (2001) Increased production of immature myeloid cells in cancer patients: a mechanism of immunosuppression in cancer. J Immunol 166:678-689

Barnes PJ, Adcock IM (2009) Glucocorticoid resistance in inflammatory diseases. Lancet 373:1905-1917

Bronte V, Zanovello P (2005) Regulation of immune responses by Larginine metabolism. Nat Rev Immunol 5:641-654

Cai W, Qin A, Guo P, Yan D, Hu F, Yang Q, Xu M, Fu Y, Zhou J, Tang $X(2013)$ Clinical significance and functional studies of myeloidderived suppressor cells in chronic hepatitis $\mathrm{C}$ patients. J Clin Immunol 33:798-808

Chang KM (2003) Immunopathogenesis of hepatitis C virus infection. Clin Liver Dis 7:89-105

Chen S, Akbar SM, Abe M, Hiasa Y, Onji M (2011) Immunosuppressive functions of hepatic myeloid-derived suppressor cells of normal mice and in a murine model of chronic hepatitis $B$ virus. Clin Exp Immunol 166:134-142

Cheng SE, Lee IT, Lin CC, Wu WL, Hsiao LD, Yang CM (2013) ATP mediates NADPH oxidase/ROS generation and COX-2/PGE2 expression in A549 cells: role of P2 receptor-dependent STAT3 activation. PLoS One 8:e54125

Chou HS, Hsieh CC, Yang HR, Wang L, Arakawa Y, Brown K, Wu Q, Lin F, Peters M, Fung JJ et al (2011) Hepatic stellate cells regulate immune response by way of induction of myeloid suppressor cells in mice. Hepatology 53:1007-1019

Cripps JG, Gorham JD (2011) MDSC in autoimmunity. Int Immunopharmacol 11:789-793

Czaja AJ, Davis GL, Ludwig J, Taswell HF (1984) Complete resolution of inflammatory activity following corticosteroid treatment of Hbsag-negative chronic active hepatitis. Hepatology $4: 622-627$

Ducci H, Katz R (1952) Cortisone, Acth and antibiotics in fulminant hepatitis. Gastroenterology 21:357-374
Elenkov IJ, Chrousos GP (1999) Stress hormones, Th1/Th2 patterns, Pro/Anti-inflammatory cytokines and susceptibility to disease. Trends Endocrinol Metab 10:359-368

Erhardt A, Biburger M, Papadopoulos T, Tiegs G (2007) IL-10, regulatory $T$ cells, and Kupffer cells mediate tolerance in concanavalin A-induced liver injury in mice. Hepatology 45:475-485

Franchimont D, Galon J, Gadina M, Visconti R, Zhou Y, Aringer M, Frucht DM, Chrousos GP, O'Shea JJ (2000) Inhibition of Th1 immune response by glucocorticoids: dexamethasone selectively inhibits IL-12-induced Stat4 phosphorylation in T lymphocytes. J Immunol 164:1768-1774

Fujiwara K, Yasui S, Okitsu K, Yonemitsu Y, Oda S, Yokosuka O (2010) The requirement for a sufficient period of corticosteroid treatment in combination with nucleoside analogue for severe acute exacerbation of chronic hepatitis B. J Gastroenterol 45:1255-1262

Gabrilovich D (2004) Mechanisms and functional significance of tumour-induced dendritic-cell defects. Nat Rev Immunol 4:941-952

Gabrilovich DI, Nagaraj S (2009) Myeloid-derived suppressor cells as regulators of the immune system. Nat Rev Immunol 9:162174

Gabrilovich DI, Ostrand-Rosenberg S, Bronte V (2012) Coordinated regulation of myeloid cells by tumours. Nat Rev Immunol 12:253268

Garcia MR, Ledgerwood L, Yang Y, Xu J, Lal G, Burrell B, Ma G, Hashimoto D, Li Y, Boros P et al (2010) Monocytic suppressive cells mediate cardiovascular transplantation tolerance in mice. J Clin Invest 120:2486-2496

Greten TF, Manns MP, Korangy F (2011) Myeloid derived suppressor cells in human diseases. Int Immunopharmacol 11:802-807

Haverkamp JM, Crist SA, Elzey BD, Cimen C, Ratliff TL (2011) In vivo suppressive function of myeloid-derived suppressor cells is limited to the inflammatory site. Eur J Immunol 41:749-759

Hegde VL, Nagarkatti PS, Nagarkatti M (2011) Role of myeloidderived suppressor cells in amelioration of experimental autoimmune hepatitis following activation of TRPV1 receptors by cannabidiol. PLoS One 6:e18281

Hines IN, Kremer M, Isayama F, Perry AW, Milton RJ, Black AL, Byrd $\mathrm{CL}$, Wheeler MD (2007) Impaired liver regeneration and increased oval cell numbers following $T$ cell-mediated hepatitis. Hepatology 46:229-241

Hong F, Jaruga B, Kim WH, Radaeva S, El-Assal ON, Tian Z, Nguyen VA, Gao B (2002) Opposing roles of STAT1 and STAT3 in T cell-mediated hepatitis: regulation by SOCS. J Clin Invest 110:1503-1513

Ilkovitch D, Lopez DM (2009) The liver is a site for tumor-induced myeloid-derived suppressor cell accumulation and immunosuppression. Cancer Res 69:5514-5521

Jaruga B, Hong F, Sun R, Radaeva S, Gao B (2003) Crucial role of IL-4/STAT6 in T cell-mediated hepatitis: Up-regulating eotaxins and IL-5 and recruiting leukocytes. J Immunol 171:3233-3244

Lafdil F, Wang H, Park O, Zhang W, Moritoki Y, Yin S, Fu XY, Gershwin ME, Lian ZX, Gao B (2009) Myeloid STAT3 inhibits T cell-mediated hepatitis by regulating $\mathrm{T}$ helper 1 cytokine and interleukin-17 production. Gastroenterology 137(2125-2135): e2121-e2122 
Lee RWJ, Creed TJ, Schewitz LP, Newcomb PV, Nicholson LB, Dick $A D$, Dayan CM (2007) CD4(+)CD25(int) T cells in inflammatory diseases refractory to treatment with Glucocorticoids. J Immunol 179:7941-7948

Li HQ, Han YM, Guo QL, Zhang MG, Cao XT (2009) Cancerexpanded myeloid-derived suppressor cells induce anergy of NK cells through membrane-bound TGF-beta 1. J Immunol 182:240249

Nagaraj S, Gupta K, Pisarev V, Kinarsky L, Sherman S, Kang L, Herber DL, Schneck J, Gabrilovich DI (2007) Altered recognition of antigen is a mechanism of CD8+ T cell tolerance in cancer. Nat Med 13:828-835

Pan PY, Wang GX, Yin B, Ozao J, Ku T, Divino CM, Chen SH (2008) Reversion of immune tolerance in advanced malignancy: modulation of myeloid-derived suppressor cell development by blockade of stem-cell factor function. Blood 111:219-228

Radaeva S, Sun R, Pan HN, Hong F, Gao B (2004) Interleukin 22 (IL-22) plays a protective role in T cell-mediated murine hepatitis: IL-22 is a survival factor for hepatocytes via STAT3 activation. Hepatology 39:1332-1342

Rehermann B (2000) Intrahepatic T cells in hepatitis B: viral control versus liver cell injury. J Exp Med 191:1263-1268

Richman LK, Klingenstein RJ, Richman JA, Strober W, Berzofsky JA (1979) Murine Kupffer cell. 1. Characterization of the cell serving accessory function in antigen-specific T-cell proliferation. J Immunol 123:2602-2609

Rodriguez PC, Quiceno DG, Ochoa AC (2007) L-arginine availability regulates T-lymphocyte cell-cycle progression. Blood 109:15681573

Rosen HR, Miner C, Sasaki AW, Lewinsohn DM, Conrad AJ, Bakke A, Bouwer HGA, Hinrichs DJ (2002) Frequencies of HCV-specific effector CD4+T cells by flow cytometry: correlation with clinical disease stages. Hepatology 35:190-198

Schleimer RP, Kato A, Peters A, Conley D, Kim J, Liu MC, Harris KE, Kuperman DA, Chandra R, Favoreto S Jr et al (2009) Epithelium, inflammation, and immunity in the upper airways of humans: studies in chronic rhinosinusitis. Proc Am Thorac Soc 6:288-294

Suda T, Chida K, Matsuda H, Hashizume H, Ide K, Yokomura K, Suzuki K, Kuwata H, Miwa S, Nakano H et al (2003) High-dose intravenous glucocorticoid therapy abrogates circulating dendritic cells. J Allergy Clin Immunol 112:1237-1239

Tacke RS, Lee HC, Goh C, Courtney J, Polyak SJ, Rosen HR, Hahn YS (2012) Myeloid suppressor cells induced by hepatitis $C$ virus suppress T-cell responses through the production of reactive oxygen species. Hepatology 55:343-353

Takahashi K, Murakami M, Kikuchi H, Oshima Y, Kubohara Y (2011) Derivatives of Dictyostelium differentiation-inducing factors promote mitogen-activated IL-2 production via AP-1 in Jurkat cells. Life Sci 88:480-485

Tiegs G (2007) Cellular and cytokine-mediated mechanisms of inflammation and its modulation in immune-mediated liver injury. Z Gastroenterol 45:63-70

Varga G, Ehrchen J, Tsianakas A, Tenbrock K, Rattenholl A, Seeliger S, Mack M, Roth J, Sunderkoetter C (2008) Glucocorticoids induce an activated, anti-inflammatory monocyte subset in mice that resembles myeloid-derived suppressor cells. J Leukoc Biol 84:644-650

Wolf D, Hallmann R, Sass G, Sixt M, Kusters S, Fregien B, Trautwein C, Tiegs G (2001) TNF-alpha-induced expression of adhesion molecules in the liver is under the control of TNFR1relevance for concanavalin A-induced hepatitis. J Immunol 166:1300-1307

Xia S, Sha H, Yang L, Ji Y, Ostrand-Rosenberg S, Qi L (2011) Gr-1+ $\mathrm{CD} 11 \mathrm{~b}+$ myeloid-derived suppressor cells suppress inflammation and promote insulin sensitivity in obesity. J Biol Chem 286:23591-23599

Yin B, Ma G, Yen CY, Zhou Z, Wang GX, Divino CM, Casares S, Chen SH, Yang WC, Pan PY (2010) Myeloid-derived suppressor cells prevent type 1 diabetes in murine models. J Immunol 185:5828-5834

Yu S, Fang Y, Sharp GC, Braley-Mullen H (2010) Transgenic expression of TGF-beta on thyrocytes inhibits development of spontaneous autoimmune thyroiditis and increases regulatory $T$ cells in thyroids of NOD.H-2h4 mice. J Immunol 184:5352-5359

Zhang J, Wang B, Zhang W, Wei Y, Bian Z, Zhang CY, Li L, Zen K (2013) Protein tyrosine phosphatase 1B deficiency ameliorates murine experimental colitis via the expansion of myeloid-derived suppressor cells. PLoS One 8:e70828 